\title{
Tax System and Rates in the Republic of Kosovo and Their Comparison with the Balkan Countries
}

Refik Kryeziu $^{1}$

RESEARCH

ARTICLE

\begin{tabular}{|c|c|}
\hline ARTICLE INFO & A B S T R A C T \\
\hline Submitted : 31.03 .2019 & In this study Tax System and Rates in the Republic of Kosovo and Their \\
\hline Revised : 30.04 .2019 & Comparison with the Balkan Countries. During the research, we have \\
\hline Accepted : 04.07.2019 & noticed that changes in tax rates, expansion of the taxable base, and \\
\hline Available : 30.07 .2019 & $\begin{array}{l}\text { creation of conditions for economic development which have constantly } \\
\text { been changing in Kosovo and Balkan countries. Although the tax system in }\end{array}$ \\
\hline $\begin{array}{l}\text { iThenticate similarity } \\
\text { score: } 14 \%\end{array}$ & $\begin{array}{l}\text { Kosovo is new, it is competitive not only in the region but even beyond it. } \\
\text { In the new fiscal package of } 2015 \text {, tax rates had changed. Personal Income } \\
\text { Taxes have reduced some of the revenues corporate taxation up to } 10 \%\end{array}$ \\
\hline JEL classification: & insurance companies $7 \%$ to $5 \%$; VAT is applied with two tax rates $18 \%$ and \\
\hline $\mathrm{H} 20, \mathrm{H} 21, \mathrm{H} 24, \mathrm{H} 70$ & $8 \%$. Balkan states have significant differences in tax rates, but not in tax \\
\hline Keywords: & systems. In some taxes, high rates have already been set, while in some \\
\hline $\begin{array}{l}\text { Taxes, Tax Rates, Tax } \\
\text { System, Reforms and } \\
\text { Comparison }\end{array}$ & $\begin{array}{l}\text { countries there are lower rates. It is characteristic and interesting that the } \\
\text { tax systems of these countries have been constantly reformed, reducing } \\
\text { tax rates and redefining the tax base. }\end{array}$ \\
\hline
\end{tabular}

\section{Introduction}

In this paper, we present the functioning of the tax system in the Republic of Kosovo and the comparison of tax rates with Balkan countries. The paper continues

Cite this article as: Kryeziu R. (2019). "Tax System and Rates in the Republic of Kosovo and Their Comparison with the Balkan Countries", International Journal of Public Finance, 4(1), 49-58.

\footnotetext{
1 Assist. Prof. Dr., ORCID: 0000-0001-8628-6166, Kadri Zeka University, Gjilan, Kosovo, refik.kryeziu@uni-gjilan.net
} 
dealing with the tax system and norm, where many economists and financiers from different countries have taken up this issue. In the continuation of the work, the focus of addressing this problem will be related to the process of building and developing the tax system in Kosovo starting with customs, excise, presumptive tax, value added tax, income tax, corporation tax, property tax and contributions. In the continuation of the paper we will analyze the development and functioning of the tax system in the Balkan countries to debate the tax rates, the effects of this system on the development of certain sectors and the economy in general.

\section{Review of Literature}

The designing of an appropriate and functional taxation reform has not been an easy objective to be reached in any of the Balkan countries. Difficulties have especially arisen in making the reforms acceptable and then successfully implementable. The taxation reforms management has been during the whole taxation reform process, from the inspection of the state until now, a long and complicated process and it still continues to be. This is due to the fact that all post-communist countries possessed taxation systems drafted for the planned economy and incompatible with the market economy and with a tax administration which needed a complete reorganization for the purpose of a successful operation in new conditions (Tanzi, 2002: 11). The economic transition brought new and unique challenges to the Balkan countries. Some of them we have treated here below (in the following): 1) In the '90s, the taxation systems of post-communist countries are characteristic for: a) non-transparency, b) differences in tax charges by means of which the discrimination of certain activities and factors and at the same time favoring of the others was done; c) there was no balance between direct and indirect taxes; d) the frequent changes in taxation systems and in certain taxes (especially on the turnover rates) as a consequence of an unsustainable tax policy; e) complex administrative procedures; f) incompatibility with the tax systems of West European countries; g) non-flexibility and nonsimplicity. Mojsoska-Blazevski's (2011) research on the influence of labour legislation changes over the employment rate and the size of the informal economy showed a marginal effect of the flat tax policy. The author finds that the reduction of social security contributions had a positive impact on the employment rate, in contrast with the impact of the flat tax reform.' She concludes that the social security and tax reforms aimed at reducing labour costs had the following positive effects: (a) helped employees during the crisis, (b) had an effect on employment, (c) increased the net wage, (d) diminished the extent of informal economy, (e) improved tax compliance, the and ( $f$ ) increased the number of individuals insured in the pension system 
(Grabowski \& Tomalak, 2004: 251). Trpeski \& Tashevska (2012) the overall tax burden in Macedonia remains low in the period of 2010-2016. However the tax burden remained relatively high in particular for low skilled labour, "caused by the minimum base for payment of social insurance contributions, which was prescribed at $65 \%$ of the national average wage rather than on the individual wage and at around $50 \%$ for health insurance on average (differentiated by branches, with higher relative burden on branches with lower average wages). Kreso \& Lazovic-Pita (2011) study the labour tax burden in the Balkan countries with flat tax rates: Macedonia, Montenegro and Bosnia and Herzegovina.

\section{Purpose of Tax System}

Existence and functioning of tax types in different countries regardless of the level of economic development form the tax system where certain goals are achieved. Through the tax system, the collection of financial means on setting up budget revenues, the financing of economic and functional categories, development of the economy, improvement of its structure, alleviation of social effect and other problems. For the purposes of taxation, many authors from different countries have been taken into consideration, depending on economic and financial developments, especially those who pay great attention to taxation. The tax system represents all taxes levied in a co-existent country with which the fiscal policy goal can be applied. Taxes are one of the forms through which the state earns revenue (Limani, 1994: 128). Hence, it follows that the purpose of the tax is to collect the financial means for the state that are necessary for the financing of their functions (Komoni, 2008: 47). With other taxation policies, other objectives can be achieved in the economy by making allowances or discounts, benefits for certain products and certain sectors of the economy. With the tax system, the government can achieve other goals by protecting the economy from external competition. This is reflected in some economic branches, both industrial and agricultural. The place and role of any of the taxes are not the same and depends on many factors that governments decide to build the country's tax system (Brajshori, 2014: 105). The study of tax purposes is closely related to the study of the role of the state. With the expansion of the state's role, money needs also increased. Apart from the financing of increased state expenditures, taxes are increasingly being utilized for the realization of other purposes that can be taken as fiscal purposes of taxation (Jelçiq, 1985: 204). To better understand the characteristics and essence of taxation, we are examining the tax system issues and the tax rates that determine the tax policies in Kosovo by comparing with the Balkan countries. 


\section{Tax Legislation and Tax Policy in Kosovo}

Since the end of the war in 1999, a new era has begun in the Republic of Kosovo in the political, economic and budgetary terms. Through system laws, the types of taxes that make up the tax system function. Tax instruments operate on the basis of the policies in which they are applied, which are harmonized with the regulations, guidelines and laws approved "Tax Legislation of Kosovo, TAK, Publication I, 2016, Pristina". In Kosovo, the tax system is administered by the Tax Administration of Kosovo, established in January 2000, under the administration of UNMIK, and from February 2003 the powers are transferred to the Ministry of Finance. From July 2001, VAT is applied, part of the tax burden goes to customers. Since 2002, the Wage and Income Tax applies. From January 2005, Income Tax and Income Tax are replaced with Personal Income Tax (PIT), which includes natural persons and corporate income tax (CIT), legal entities (Tax system in Kosovo, 2011).

\subsection{Customs and Excise}

Customs are fiscal instruments that through state procedures collect funds at the moment of importation and exportation when goods are transferred from another country. Customs is a government agency that collects duties and controls the goods from the customs territory. In Kosovo, customs operate since 1999. UNMIK Regulation no. 1999/3 and the Administrative Direction. Taxes and procedures are defined in the Customs Law. All goods of any kind intended for Kosovo and not subject to any import ban shall be subject to a customs duty of $10 \%$ with the exception of goods for which the customs duty is equal to $0 \%$ "Customs and Excise Code, November 11, 2008". Excises are a special type of tax for certain types of products. With the calculation of excise duty, the taxable value of the goods shall consist of the total customs value plus customs duties, the value accruing from the retail price, including customs duties and excises "Regulation on Excise 2000/2". Excise duties are charged special products, specific is that although the rise in the price of the product does not significantly affect the decline in consumption. In the framework of reforming the tax system, 2009, changes were made in customs and excise, the Customs and Excise Code was approved.

\subsection{Value Added Tax (VAT)}

The VAT is a special type of turnover tax set at each stage of the production and distribution process. In the cleanest form, VAT is a tax on all final expenditures for goods and services that are delivered to the final customer. Applies to products that go through production and distribution stages, from raw material to final products and 
sales. In practice, VAT has substantial deviations because there are different degrees, exceptions for certain goods and services. With the Law on VAT, the tax rate was $15 \%$, since 2009 was 16\% "Law no. 03 / L-146 on Value Added Tax", is applicable from January 1, 2009, and is applicable from 1 January 2010 "Law no. 05 / L-037 For VAT". The most recent reforms were implemented from 01 September 2015 through the new Fiscal Package including VAT, PIT and CIT, where VAT rates are $8 \%$ and $18 \%$ depending on the supply of goods or services" Law no. 05 / L-037 For VAT".

\subsection{Personal Income Tax (PIT)}

The application of personal income tax is a direct taxin practice. PITis appled resident and non-resident persons, enterprises, partnerships and companies that generate gross income.

Personal Income Taxes are charged by these levels and sources of income:

1) For taxable income $960,00 €$ or less, $0 \%$, taxable income $960,00 €$ up to $3,000.00 €$, including the amount of $3,000.00 €, 4 \%$ of the amount over $960,00 €$, for taxable income of over $3,000 €$ to $5,400.00 €$, including the amount of $5,400.00 €, 81.6$ $€$, plus $8 \%$ of the amount over $3,000.00 €$ and for taxable income over $5,400,00 €$, $273.6 €$ plus $10 \%$ of the amount over $€ 5.400,00$.

2) Gross income from business activities with gross annual income over $50,000.00 €$, who choose to keep books and businesses less than 50,000.00 $€$, who do not choose to keep books, 3) Gross income from rents, 4) gross income from intangible property, 5) gross income from interest, and 6) other income, gifts from any source. With the recent reform of the personal income tax, taxes on interest, rent taxes, gambling, capital gains, the sale of intangible property, etc. have also decreased"Law no. 05 / L-028 on Personal Income Tax".

\subsection{Corporate Income Tax (CIT)}

In the course of the construction of the tax system, there is also profit tax "Regulation no. 2002/3 on Profit Tax in Kosovo". Profit tax is a corporation tax rate applied to the rate of 10 percent, for all economic activities and 5 percent for insurance and reinsurance companies. Profit tax is payable by corporations that realize turnover more than $100,000.00 €$ and those that possess assets in the amount of $50,000 €$. Previously it was applied only to large corporation tax profits. With the new reforms, Corporate Income Tax, in the calendar quarter is obliged to pay these taxpayers" Law no. 03 / L-161 on Personal Income": 
1. Taxpayers with annual gross income up to $50,000.00 €$ or less, who are not required to submit their annual declaration:

2. Criminal taxpayers exceeding the amount of 50,000.00 $€$ and taxpayers who have to compile financial statements:

- A quarter $(1 / 4)$ of the tax liability for the following tax period based on the estimated and reduced taxable income, whichever is severely withheld during the quarter or for the second period, the following tax periods for which the taxpayer makes the payment, at least one quarter $(1 / 4)$ of $110 \%$ of the tax liability reduced by any amount held at source during the quarter. Or CIT includes all small corporations that are themselves subject to real-estate tax, applied only to gross corporate sales "Law no. 03 / L-162 Corporate Income Tax".

\subsection{Contributions}

Contributions are non-fiscal instruments, i.e., the obligatory take-over of a portion of the profit realized by certain individuals. Contributions are paid in special funds, in a certain social program, e.g., health insurance, pensions or social security and unemployment. In the countries of the region, two pension systems, investment systems and transfers are applied:

1) PAYG (Pay As You Go is a state program funded by taxes or contributions that are collected by employees) Transfers System or Scheme, applied by some states, known as the Pay As You Go system. This system is based on the transfer of pension funds, (the Balkan countries applying the pension scheme are: Bulgaria applies since 2000, Croatia 2002 and Macedonia since 2005).

2) Investment system or investment-based pension scheme (The Transfer Scheme of Transfers applies to these countries in the region, such as: Albania, Montenegro, Bosnia and Herzegovina and Serbia) (Kryeziu, 2014: 192).

Collective contributions are made by the employer and the employee by $5 \%$ of the salary. Voluntarily can contribute, up to $10 \%$ of the annual salary, to a total of $15 \%$ of the salary (Kryeziu, 2014: 192).

\section{Tax Rates in Kosovo}

Based on the established tax policies, the various contemporary countries, in their tax systems, set the tax rates. Tax rates are set by percentage, which represents the ratio between the tax and the tax base, which serves to set the tax rate. In Kosovo, along with the development of the tax system, we have dynamics of tax rate changes. 
Kryeziu R. (2019). "Tax System and Rates in the Republic of Kosovo and Their Comparison with the Balkan Countries", International Journal of Public Finance, 4(1), 49-58.

Table 1: Change of Tax Rates, period 2005 to 2018

\begin{tabular}{|c|c|c|c|}
\hline Taxes & 2005 & 2009 & $2015-2018$ \\
\hline $\begin{array}{l}\text { Personal Income Tax } \\
\text { (PIT) }\end{array}$ & $\begin{array}{c}0-960 €-0 \%, \\
960-3000 €-5 \% \\
3000 €-5400 €-10 \% \\
\text { mbi } 5400 €-20 \%\end{array}$ & $\begin{array}{c}0-960 €-0 \% \\
960-3000 €-4 \% \\
3000 €-5400 €-8 \% \\
\text { mbi } 5400 €-10 \%\end{array}$ & $\begin{array}{c}0-960 €-0 \% \\
960-3000 €-4 \% \\
3000 €-5400 €-8 \% \\
\text { mbi } 5400 €-10 \%\end{array}$ \\
\hline \multirow{2}{*}{$\begin{array}{l}\text { Corporate Income } \\
\text { Tax (CIT) }\end{array}$} & \multirow[t]{2}{*}{$20 \%$} & $10 \%$ & $10 \%$ \\
\hline & & $\begin{array}{l}7 \% \text { Assurance } \\
\text { compensation }\end{array}$ & $\begin{array}{l}5 \% \text { Insurance } \\
\text { company }\end{array}$ \\
\hline Value aded tax VAT & $15 \%$ & $16 \%$ & $8 \%$ dhe $18 \%$ \\
\hline
\end{tabular}

Source: Processed data based on tax legislation in force.

In Table 1 we see that Kosovo has made some progress in reforming and functioning of the tax system. Setting new tax rates to some extent has also impacted on budget growth and economic growth in the country (Kryeziu, 2011: 107). In order to reflect the effects of taxes on economic development, reforms are made both in the system and in tax rates. The changes have influenced the growth of National Revenues, economic growth, and increased budget revenues (Kryeziu, 2014: 154). In this regard, the changes in tax rates in all modern countries create ideal conditions for foreign investors that affect economic development in general (Kryeziu, 2009: 28).

\section{Characteristics of the Tax System in Balkan States, Difference and Comparison between These Countries}

Major political and economic changes occurring in the 1990s in Europe and beyond have been accomplished with many objectives that have been reflected in the countries of the region in many aspects and directions, especially in the political, economic and financial aspects. Politically, the reforms have influenced the development of democracy, economic freedom is spreading, and in fiscal policy, the fiscal system has been developed and reformed, with the developed European countries. While in the Balkan countries, there are approximately the same tax systems, while with their policies there are significant differences in the establishment of norms. Total tax rates are counted as tax, tax, and contribution charges, to be calculated and paid by businesses and individuals. This burden shows the weight that a country's fiscal policy puts on residents and non-residents. Withholding tax (such as salary tax) or tax and tax collected with tax agent (VAT, sales tax) are excluded (Gjokutaj, 2016). The tax reform can be described as a dynamic process of continuous improvement of the structures of the national tax systems in order to fulfill the general economic and tax policy goals. It has been confirmed that some of the most powerful tax reform drivers from a domestic and international point of view are the general tax 
policy principals. Basic priority of the Corporate Income Tax reform in the RM is to maintain a tax structure that would enable a relatively simple and easy administration and at the same time would provide a comparatively lower corporate effective tax burden (Gruevski, 2012: 10).

In the Balkan countries, there are three main types of taxes: Personal Income Tax (PIT), Corporate Income Tax (CIT) and Value Added Tax (VAT) as well as Social Security Contributions (SSC) and Health Insurance Contributions (HIC). Personal Income Tax (PIT), Albania, Bosnia and Herzegovina, Macedonia and Montenegro apply the flat tax. In Albania it has been applied since 2007, replacing the progressive tax by up to $30 \%$. At the same time, Macedonia has passed a flat tax since 2007. Montenegro also applies the flat tax 9\%, from 2009 to $12 \%$. Croatia and Serbia, apply the progressive tax. In Croatia, PIT is escalating from $15 \%$ to $45 \%$. In Serbia, the basic rate is $10 \%$, but the self-employed pay 12\% (Pere \& Hashorva, 2011: 80). Corporate Income Tax (CIT) rates differ in Balkan countries. In Albania there is $15 \%$, Macedonia 10\%, Montenegro 9\%, Serbia 15\%, Kosovo and Bosnia with 10\% (Pere \& Hashorva, 2011: 80).

Tablo 2: Tax Rates in Balkan countries for 2016 (\%)

\begin{tabular}{|l|l|l|l|l|l|l|}
\hline \multirow{2}{*}{ States } & \multirow{2}{*}{ VAT } & \multirow{2}{*}{$\begin{array}{l}\text { Profit } \\
\text { Tax }\end{array}$} & Personal & Income Tax & Social and health insurances \\
\cline { 5 - 7 } & & & Total & Employer & Employee \\
\hline Macedonia & 5,18 & 10 & 10 & 27 & 0 & 27 \\
\hline Kosovo & 8,18 & 10 & 10 & 10 & 5 & 5 \\
\hline Croatia & $5,13,25$ & 20 & 47.2 & 37.2 & 17.2 & 20 \\
\hline Montenegro & 19 & 9 & 9 & 32.8 & 9.3 & 23.5 \\
\hline Bosnia-Herzegovina & 17 & 10 & 10 & 41.5 & 10.5 & 31 \\
\hline Bulgaria & 9,20 & 10 & 10 & 31.4 & 18.5 & 12.9 \\
\hline Albania & 20 & 5,15 & 13.23 & 27.9 & 16.7 & 11.2 \\
\hline Serbia & 20 & 15 & 15 & 37.8 & 17.9 & 19.9 \\
\hline Romania & $2,9,20$ & 16 & 16 & 54.5 & 38.45 & 16.05 \\
\hline Greece & $6,13,23$ & 29 & 46 & 40.06 & 24.56 & 15.5 \\
\hline
\end{tabular}

Source: Gjokutaj, 2016: 70.

In Table 2 we note that in the Balkan countries have differences in tax rates in 2016. Above average, VAT has Croatia and Greece, below Kosovo $18 \%$ and $8 \%$, Bosnia and Herzegovina and Montenegro. Albania 20\%, Macedonia 18\% and 5\%, Montenegro has $19 \%$, Serbia $20 \%$, Bosnia $17 \%$. For tax on profit, the tax rates in the Balkan countries over the average are Greece with $29 \%$, Croatia with $20 \%$ and Romania with $16 \%$, below average have Montenegro, Kosovo, Macedonia and Bosnia. Albania 
operates with a tax rate for profit, between the highest and the lowest. For personal income tax (including tax at source) Greece, Croatia have the highest tax rate, Romania is close to $16 \%$. The lowest level is Kosovo, Albania, Macedonia, and Bosnia. For social and health insurance contributions, Romania, Greece, Serbia, Bosnia, Croatia and Montenegro have the highest rates. Social and health insurance contributions in Romania are $54.5 \%$, employers with $38.45 \%$ and employees with $16.05 \%$. In Albania, social security contributions paid by the employer are $15 \%$ and the employee $11.20 \%$. Macedonia has all the burden transferred to the employee with the level of $27 \%$, Montenegro $5.50 \%$ and $24 \%$. In Serbia, the employer pays $17.9 \%$, while the employee is $19.60 \%$. In Kosovo, the employerpays $5 \%$ and the employee $5 \%$, in Bosnia the employer pays $10.50 \%$, while the employee is $31 \%$. One of the objectives of the tax policy and system in Kosovo and the Balkan states is to adapt to the position of national economies and the functioning of their tax systems in a continuous manner, they should improve and design their tax policies, which we consider it a good way and way for state governments to advance their tax systems and thus to develop public finances in order to be competitive with the economies of the region, the European Union and beyond.

\section{Conslusion}

During the drafting process, it came to the conclusion that the tax policies and systems in Kosovo and the Balkan states are adapting to the position of national economies and the functioning of the continuous systems of their, to improve and design them. Also in this paper we have compared the taxation of the Kosovo system with the Balkan countries and the harmonization of the system of these countries. As noted in the paper, we conclude that the governments of some Balkan countries need to reform their tax systems for the sake of consolidating their system to improve the quality of taxation compared to those currently in force.

\section{References}

Brajshori, B. (2014). Public Finance, Prishtina.

Customs and Excise Code, November 11, (04.07.2019).

Dzhekova R, Franic J., Mishkov I. \& Williams C.C. (2014), "Tackling the Undeclared Economy in FYR Macedonia", GREY Working Paper No. 3, University of Sheffield.

Gjokutaj, E. (2016). Taxation Trends in Western Balkans, ALTAX, Tirana. 
Grabowski, M. \& Tomalak, M. (2004). Taxation System Reforms in the Countriesof the Central Europeand CIS, New Europe-Reporton Transformation, Instytut Studiów Wschodni, Warsaw, 251-301.

Hutsebaut, M. (2012). Policy Taxes From a European Perspective, Eurostat, Luksemburg, http://www.bspk.org/PDF/4_4_13.pdf, (04.07.2019).

Jelçiq, B. (1985). Science on Finance and Financial Law, Prishtina.

Komoni, S. (2008). Public Finance, Prishtina.

Kryeziu, R. (2009). "Foreign Direct Investments in the Republic of Kosova and Their Impact on Economic Development". International Conference, Management Challenges During Transition, Faculty of Economy, University of Tirana.

Kryeziu, R. (2011). National Economy. Prospects for Economic Development of the Republic of Kosovo, Prishtina.

Kryeziu, R. (2014). Public Finance, Prishtina.

Kreso, S. \& Lazovic-Pita, L., (2011). "Labour tax burden in the "flattax" Western Balkanstates: a Comparison", 5th International Scientific Conference "Entrepreneurship and Macroeconomic Management: Reflectionson the World in Turmoil", Pula, Croatia.

Gruevski, I. (2012). "Corporate tax reform in Republic of Macedonia". Conference Proceedings-1st International Conference South-East European Countries toward European Integration Elbasan-Albania.

Limani, M. (1994). Economic Policy, Pristina.

Law no. 03 / L-146 on Value Added Tax (04.07.2019).

Law no. 03 / L-161 on Personal Income (04.07.2019).

Law no. 03 / L-162 Corporate Income Tax (04.07.2019).

Law no. 05 / L-037 For VAT (04.07.2019).

Pere, E. \& Hashorva, A. (2011). "Tax Systems in West Balkans Countries-Between Simplicity and Efficiency", Romanian Economic and Business Review, 6(2), 8094.

Regulation on Excise 2000/2 (04.07.2019).

Tanzi, V. (2002). Fiscal Policies in Economies in Transition, IMF, Washington.

Trpeski, P. \& Tashevska, B. (2012). "Labour Tax Wedge in the Republic of MacedoniaTrendsand International Comparison". Annales Universitatis Apulensis Series Oeconomica, 14(2), 571-585.

Tax System in Kosovo (2011). https://mf.rks-gov.net/desk/inc/media/F0D54917-C3484F9A-8DBF-D0360F73D788.pdf (04.07.2019).

Tax Legislation of Kosovo (2016). TAK, Publication I, Pristina. 